\title{
ROLE OF THE SUFIS DURING THE PANDEMIC IN A SOCIETY: COVID-19 in Nigeria as a Case Study
}

\author{
Abdur-Razzaq Mustapha Balogun Solagberu \\ Kwara State College of Arabic and Islamic Legal Studies Ilorin, Nigeria \\ solagberuabdurrazzaq@gmail.com
}

Article History: Received: 4 October 2021; Accepted: 14 December 2021; Published: 24 December 2021

\begin{abstract}
:
COVID - 19 is the code given to an infectious disease called Coronavirus. It was on $31^{\text {st }}$ December 2019 that World Health Organization (WHO) was kept informed of its discovery. It was speculated that the disease was first discovered in the Republic of China. It then spread from there to other countries of the world, including Nigeria. Multiple efforts were put in place in an attempt to halt its spread in the country, i.e., Nigeria. One of such was to lockdown the country. The pandemic and lockdown had various effects on society and its people in multiple ways. As a result, people found themselves in a state of frustration and anxiety, looking forward to a remedy and solution. This paper, therefore, determines to examine the role of the Sufis during this kind of situation with the hope of bringing the role of the Sufis into the limelight and to put it on record the Sufi resilience and effort on the spiritual being of the Sufi adherents at a particular time. The method adopted in this research is based on the interpretative approach in line with the disciplines of Islamic Studies, especially Sufism and history. The main result of the study reveals that the pandemic has both positive and negative effects on people generally. Finally, through its teachings, Sufism provides resilience to the public, especially its adherents.
\end{abstract}

Key Words: COVID 19; Nigeria; Sufism

\section{A. Introduction}

ufism or Tașawwuf is Islamic mysticism. It can also be interpreted as the esoteric S or inner dimension of Islam. Its historical development could be traced back to the prophetic period, considering the fact that there are some Qur'anic verses which are mystical in nature. Typical reference can be made to the Qur'an 18 verses 66 to 82 and the Qur' an 27 verses 39 and 40. While the former is on the encounter between Prophet Musa (A.S) and a mystical scholar known as Khidr, the verses also discuss about the mystical incidents that occurred. The latter on the other hand refers to the historical event whereby another mystical scholar called 'Āsif ibn Barkhiya mystically brought the throne of Queen Bilqis before King/Prophet Sulaymān (A.S). 
Meanwhile, the essence of Sufism is to provide spiritual training and selfpurification to its adherents and by extension to the Muslim populace. ${ }^{1}$ The practice is called Tașawwuf, while the adherent is identified as a Sufi. Since its emergence, it has continued to be spread to all parts of the Muslim World. In point of fact, Sufis are identified as one of the major factors for the spread and understanding of Islam, especially in West Africa. ${ }^{2}$ Other factors include (i) activities of Du'ät (Muslim missionaries) (ii) Muslim traders (iii) Some Muslim individuals or converted rulers among many others. Added to that, Ezzati lists many other activities which he considers as instrumental factors for the spread of Islam. Those listed as factors are Islamic tolerance, Islamic spiritual factors, Islamic leadership factors, intellectual factor, moral factors, cultural factors, political factors, and a host of many others. ${ }^{3}$

However, Sufis as a factor have been playing multifarious roles in a given society. These activities of the Sufis have attracted the attention of academics as well as other scholars of high repute. For instance, Shaykh Ibrahim Sālih in his book entitled: AtTakfir discusses the role of the Sufis in the spread of Islam. ${ }^{4}$ Similarly, Shaykh al-Ilori (d. 1992 CE) has a book on the influence of the Sufis among others on the spread of Islam. ${ }^{5}$ Also, Abdur-Razzaq Solagberu has a paper on the role of the Sufi in the spread of literacy in Nigeria. ${ }^{6}$ In addition to that, Professor Quadri specifically examines the role of the itinerant Muqaddams in the spread of the Tijaniyya. ${ }^{7}$ The list cannot be exhausted. The present research work is on the Role of the Sufis during the pandemic in a society with a particular reference to COVID-19 in Nigeria. The topics may look identical but they are not the same. This present work is a departure from the previous ones. Its focus is on the role of the Sufis during pandemic with the aim of bringing to the limelight, the role played by the Sufis as a result of which spiritual conducive atmosphere was created and Sufi resilience was achieved.

1 A.K. Brohi, "Doctrine of Tasawwuf" in Khurshid Ahmad (Ed) Islam in the Modern World (Lahore. Pakistan, Publishers United Ltd. 1975), 17. See also Mir Valiudden, The Qur'anic Sufism (Delhi Pakistan Motilal Banarsidass 1977, 3.

2 P.O. Olat unbosun, School Certificate GCE History of West African, $5^{\text {th }}$ ed. (Ilesha-Nigeria: Fatiregun Press, 1981), 79.

3 Abdul-Fazl Ezzati, An Introduction to the History of the Spread of Islam (Lagos-Nigeria: Islamic Publications Bureau, 1979).

4 Ibrahim Sālih B. Yunus, At-Takfir Ahtar Bidcah Tuhadid As-Salam Wal-Wahdat Bayn Al-Muslimin Fi Naijiiriyyā (Cairo: Sharkat Maktabat Wa Matbacah Mustafa al-Bābī al-Halabi wa awlādau, 1982), 4-7.

5 Ādam Abdullahi Al-Ilori, Āthār Al-Falsafah Wat-Tasawwuf Wal-'Ilm Fi Masirah Ad-Da'Wah AlIslamiyyah (Cairo: Matba'ah al-Madni, 1982), 42-75.

6 Abdur-Razzaq Mustapha Balogun Solagberu, "The Role of the Sufis in the Spread of Literacy in Nigeria," Allawh: Journal of Arabic and Islamic Studies 2, no. 4 (2009): 228-43.

7 Y.A. Quadri, "The Role of the Itinerant Muqaddams in the Spread of the Tijaniyyah," Islamic Studies, Quarterly Journal XXII, no. 2 (1983): 17-29. https://www.jstor.org/stable/23076048. 


\section{B. Islam in Nigeria}

Islam in the region pre-dated the history of where is called Nigeria today. This is based on the fact that Nigeria as a nation is traced back to 1914 when the amalgamation between Northern and Southern protectorates took place, it was then placed under the governorship of Sir Frederick Lugard. Although the name for the country was earlier suggested in 1902 by one Flora Shaw a proposed wife of Lugard. ${ }^{8}$ Prior to that time, the country was made up of different kingdoms and various empires with many ethnic groups and societies, living in a different section of the country. It was prior to the 1914 Amalgamation that Islam was introduced to a country, although there are divergent views on the actual time, perhaps that was due to the fact that Islam reached various sections of the country at different times. For instance, Islam is suggested to have spread to the then Kanem-Borno empire by the Eleventh Century of the Christian Era, when the Mani (King) of Kanem known as Umme Jilmi, in the year 1086 CE embraced Islam through an itinerant Islamic scholar named Muhammad Ibn Mani. ${ }^{9}$ Other dates, according to Olayiwola have been suggested, such as the seventh, eighth, and tenth centuries. ${ }^{10}$ In another part of the country like in the Hausa States, it is on record that Islam penetrated into the area in the earlier part of the fourteenth century. A typical reference can be made to Kano, whose king named Ali Yaji Dan Tsamiya (1349 - 85 CE) was reported to have embraced Islam from the Wangarawa scholars, numbering about forty from the present Republic of Mali of West Africa introduced Islam to the King, and through him, the religion of Islam spread to other parts of Hausa Land. ${ }^{11}$ In Yoruba Land, there are divergent views on the time when the spread of Islam began in the area. While Fajana and Biggs suggest the tail end of eighteen century as the time when Islam was introduced to Yoruba land. ${ }^{12}$ The same date was suggested by Samuel Johnson. ${ }^{13}$ Abdur-Rahman Doi on the other hand, calculates the date to be around Sixteenth Century citing a Timbuktu Muslim itinerant scholar, Ahmad Baba, who died in $1610 \mathrm{CE}$, was reported to have observed the existence of Islam in Yoruba land as contained in his report. ${ }^{14}$ Still, on the history of Islam in Yoruba land, Ādam Abdullahi al-Ilorī (d. 1992) suggests the fourteenth century basing his suggestion on the activities of a Malian King, Al-hajj Mansa Musa (d. 1337 CE), stating that during his lifetime,

8 Rex Akpofure Michael Crowder, Nigeria: A Modern History for Schools (London: Feber and Feber, 1966), 17.

9 Chinedu N. Ubah, Islam in Africa History (Nigeria: Kaduna Baraka Press and Publishers Limited, 2001), 154.

10 Abdul Fattah Olayiwola, Islam in Nigeria: One Cresent Many Focuses (Lagos: Nigeria Olucouger Prints, 2014), 11.

11 J.A. Burdon, Northern Nigeria. Historical Notes on Certain Emirates and Tribes (London: Watnow \& son Limited, 1972), 24.

12 A. Fajana and B.J. Biggs, Nigeria in History (Ibadan: Longman Nigeria Limited, 1976), 178.

13 Sameul Johnson, History of the Yorubas (Lagos: Nigeria C.SS limited, 2001), 26.

14 Abdur-Rahman I. Doi, Islam in Nigeria (Zaria: Nigeria Gaskiya Corporation, 1984), 109.

Teosofia: Indonesian Journal of Islamic Mysticism, Vol. 10, No. 2, 2021 
Islam had penetrated into Yoruba land. ${ }^{15}$ Whichever be the date of Islam penetration into Nigeria, the divergence of views confirm the presence of Islam in Nigeria for a long period of time. Since then, Islamic religious activities have continued to be performed as stipulated by the religion. One of the major key players in the propagation and the spread of Islam in the country is the Sufis.

\section{Sufism in Nigeria}

Sufism as the mystical dimension of Islam is based on the esoteric understanding of the Qur'ān, it is also viewed as an aspect within which the sources of the Muslim philosophical thought are gleaned. ${ }^{16}$ It has continued to play a prominent role in the spread of Islam in the World. Considering its role in African countries, it is believed that Islam together with some Sufi tendencies like asceticism (zuhūd). Spread simultaneously to the continent at the same time. ${ }^{17}$ Added to that, history had it that some individual Sufi scholars and later, members of the organized Sufi order (Tañqa) contributed to the process of Islamizing many tribes in Africa. ${ }^{18}$ They are known to have adopted different methods in preaching, teaching, and spreading the tenets of Islam. These include offering practical solutions to the problems confronting the converts such as providing concrete materials with extra-ordinary power that could neutralize evil forces facing the converts with the main objective of making them be steadfast in the religion. ${ }^{19}$

Of all the Sufi Orders in the Muslim world, two are more pronounced in Nigeria. These are Qadiriyya and Tijaniyya. The Qadiriyya is believed to have been founded by Shaykh 'Abdul-Qādir al-Jīlān̄̄ (1077 - 1166 CE) in Baghdad. However, it has been speculated that there was no evidence that the Shaykh ever claimed to have an order or initiated anybody. ${ }^{20}$ The speculation has been faulted. ${ }^{21}$ Nevertheless, the Order spread from Iraq to other parts of the world such as Syria. The adherents of the order are trained in Islamic jurisprudence and science as well as mysticism. ${ }^{22}$ The Tijaniyya on the other hand was established by Shaykh Ahmad bn Muhammad bn Mukhtar at - Tijani (1737 $1815 \mathrm{CE}$ ) in Fez, Morocco, and was widely spread and accepted almost immediately after its establishment especially in the North and West African countries. ${ }^{23}$

15 Adam Abdullahi Al-Ilori, Al-Islām Fi Naijiriyya Wash-Shaykh 'Uthman Bin Fudiye Al-Fulāni (Cairo, 1971), 33

16 C.A. Qadri, Philosophy and Science in Islamic World (London: Routledge, 1991), 89.

17 Olayiwola, Islam in Nigeria,... 216.

18 Olayiwola, Islam in Nigeria,.... 216.

19 Olatunbosun, School Certificate GCE History of West African, 79.

20 J. Spencer \& Framingham, The Sufi Orders in Islam (London Oxford University Press, 1971). 42.

21 For detail see Abdur-Razzaq Mustapha Balogun Solagberu, "Sufi versus Anti- Sufi in Ilorin Nigeria: A Struggle for Supremacy," in Ilorin: History, Culture and Lessons of Peaceful Co-Existence, ed. A.G.A.S Oladosun et al. (Ilorin: Centre for Ilorin Studies, University of Ilorin, Nigeria, 2013), 3-4.

22 Peter B. Clarke, West Africa and Islam (London: Edward Arnold Limited, 1982), 31.

23 Olayiwola, Islam in Nigeria,... 219. 
Chronologically, the Qadiriyya Order predated Tijaniyya order into Nigeria. It is very difficult to state categorically the time when the Qadiriyya was introduced into the country, because of the availability of multiple personalities associated with the spread of the order in the country. ${ }^{24}$ Similarly, the time of the entry of the Tijaniyya Sufi order into Nigeria. That notwithstanding, the presence of the Tijaniyya in the country is confirmed. The combined effect of all these is meant to establish the fact that Sufi Orders especially the Qadiriyya and Tijaniyya are well pronounced in Nigeria with multiple adherents who spearheaded the spread and the teachings of Islam. ${ }^{25}$

\section{The Role of the Sufis in the Society}

The role of the Sufis in society can be discussed from the perspectives in which the institution of Sufism is assessed. For instance, in a book of joint-authorship by Isma‘īl Rājī al-Fārūqī entitled "The cultural Atlas of Islam”, where Sufism is presented as a movement of both great good and great evil in the history of Islamic civilization. According to the authors;

"Tașawwuf... a movement that dominated the minds and hearts of Muslims for a millennium, and is still strong in many circles of the Muslim World. It nourished their souls, purified their hearts, and fulfilled their yearning for piety, for virtue and righteousness, and for closeness to God. It grew and rapidly moved to every corner of the Muslim world. It was responsible for the conversion of millions to Islam as well as for a number of militant states and socio-political movements. It was equally responsible for the eclipse of Muslim power, for the Muslims exchange of rationale for intuitive, and critical for superstitious knowledge, for their forsaking of this world and its concerns for the other." ${ }^{26}$

The adequacy or otherwise of this assessment is beyond the scope of this research paper. However, this assessment points out the controversial stat us of Sufism as well as draws attention to the expected and anticipated role of the Sufis in society. Based on that. It is believed that the Sufis have multiple roles to play in any given community. The roles could not be restricted to spiritual matters alone, considering the fact that Islam, as practiced by Prophet Muhammad (SAW), was not limited to spiritual issues only. This is based on the fact that Islam is a complete way of life and it does not create a demarcation between the performance of religious duties and involvement in social, economic as well as political activities. This shows that Islam disagrees with the Biblical statement that states "render unto Caesar the things which are caesar's and unto God the things which are God's." ${ }^{27}$ In Islam, everything belongs to God, Caesar himself inclusive. In view of the above explanation, one is given to know that the role of Sufism

24 Solagberu, "The Role of the Sufis in the Spread of Literacy in Nigeria," ... 230.

25 Solagberu, "The Role of the Sufis in the Spread of Literacy in Nigeria." ... 230.

26 Ismā' il R. Al-Farūqī and Lois Lamya Al-Faruqi, The Cultural Atlas of Islam (New York: Macmillan Publishing Company \& London: Collier Macmillan Publishers, 1986), 295.

27 See Bible, Mathew 22:21.

Teosofia: Indonesian Journal of Islamic Mysticism, Vol. 10, No. 2, 2021 
in society includes, religious propagation, spiritual training, as well as socio-politicaleconomic matters as well as education and medical issues. All these have been accomplished by them i.e. the Sufis irrespective of space and time. In Nigeria, the roles of the Sufis in the above matter are manifested.

Sufism as a mystical dimension of Islam, based on the esoteric of the Glorious Qur'ān is one of the truly creative manifestations of the religious life of Islam. It is also considered as an Islamic science that enables responsible Muslims to acquire praiseworthy qualities and keep away from blameworthy attributes. ${ }^{28}$ It has continued to play an important role in the spread of Islam. In Nigeria like many other African countries, Islam and Sufi tendencies such as asceticism entered into the continent at the same time and spread simultaneously ${ }^{29}$ Sufi adherents and later Sufi Orders contributed to the process of the Islamization of many tribes of various countries of Africa. ${ }^{30}$ It is also observed that the role of the Sufi scholars in the development of literacy and scholarship was enormous. ${ }^{31}$ Reference has to be made to the Mosque establishment at Sharifai in Nigeria by Shaykh Abū Abdullah Muhammad bin Abdul Karīm al-Maghilī (d. 1504) during his visit to Kano, Nigeria. ${ }^{32}$ The Mosque also served as Zawiya, as well as a training center. In addition to the construction of the mosque, al-Maghilii also wrote a treatise on politics as a guidance for the Emir of Kano, Muhammad Rumfa (1463 99CE). ${ }^{33}$ The title of the work is "Tajud-Dīn Fì Mā Yajib "alal Mulük" translated as "The crown of Religion pertaining to the obligations of rulers." Another significant contribution made by the Sufis to literacy was the establishment of a large zawiya at a place called Kulimbardu in Borno in Old Kanem - Borno 1600 - 1660 CE. ${ }^{34}$ The zawiya served not only as a place of worship but also as an intellectual training center. The role of the Sufis on education and literacy is also manifested in the establishment of the Old Kano Law School. The school was an outcome of a proposal presented by the Emir of Kano, Al-Hajj Abdullahi Bayero (d. 1953 CE) to the colonial rulers in the country. The proposal was approved and the "Law School" was established in 1934, sited at Katsina, under Katsina College. It was in 1947 that the school was relocated to Kano and renamed school for Arabic studies (S.A.S). ${ }^{35}$

28 Ibrahim Ado-Kurawa, Shari'ah and the Press in Nigeria, Islam versus Western Christian Civilization (Kano: Kurawa Holdings Limited, 2000), 229.

29 Olayiwola, Islam in Nigeria,... 216.

30 Olayiwola, Islam in Nigeria,... 216.

31 Ubah, Islam in Africa History,... 262.

32 Muhammad Sani Zahradeen, "The Place of Mosque in the History of Kano," in Studies in the History of Kano, ed. Bawuro M. Barkindo (Kano: Department of History, Bayero University, 1983), 58. See also Ādam Abdullahi Al-Ilori, Alİmām Al-Maghili (Cairo: Maktabah wa Matia'ah al-Mustafa al-Bābi al-Halabi wa awlādau, 1979), 39.

33 Muhammad Sani Zahradeen, "The Place of Mosque in the History of Kano" 58

34 A.F. Ahmed, "The Spread of the Qadiriyyah in Borno and Hausa Land before the Fulani Jihad," Journal of the Nigeria Association of Teachers of Arabic and Islamic Studies 3, no. 1-4 (1983): 7.

35 Abdul Rauf Saliu, "A Critical Study of the Contribution of the School for Arabic Studies to the Development of Arabic and Islamic Studies in Nigeria" (Ilorin, 1988), 9-11. See also Abubakar 
In addition to the role played by those Sufi scholars above on literacy and scholarship, there were many others, not mentioned, who made similar contributions, they were made up of different genders. A typical example is a role played by one of the daughters of Shaykh 'Uthman Ibn Fodio (d. 1817 CE) in the person of Nana Asma'u $(1793$ - $1864 \mathrm{CE})$. She had almost sixty-six volumes of works to her credit. ${ }^{36}$ The body of her works is based on different aspects and as a result of the focus of her works, she was identified as a Sufi woman scholar, a jurist as well as a political scientist. ${ }^{37}$ Apart from her scholarship role mentioned above, she also played a positive and concrete role in socio-economic and political affairs in society. Reference has to be made to the educational center which she established. She used the center to impart knowledge to her students who were trained teachers, who on their own contributed to the spread of her teachings. The Centre was specialized for women gender only. She organized them to be taking lessons in groups as the students came to the Centre from different territorial areas. The Educational Centre of Asma'u was known as Yan Taru. ${ }^{38}$ The Centre i.e. Yan Taru was used by the founder, Nana Asma'u to popularize women's education, perhaps she imbibed such an idea from her father, Shaykh 'Uthman Ibn Fodio who encouraged women education. Nana Asma'u initiated a struct ure among the members' group coming from the village or location and the title Jaji was given to the leader of the movement of a particular location, and a hat (Malfa) was used to be given to Jaji as a symbol of authority. ${ }^{39}$ Nana Asma'u as a leader and scholar served her community by working for its interests through multifarious activities, such as the followings:

a. Organizing/Engaging herself in the distribution of food and clothes to the needies.

b. Helping the widows and orphans in various ways.

c. Organizing food supplies for the army.

d. Educating women and providing them with leadership qualities. ${ }^{40}$

With all these, Nana Asma'u activities are termed politico-philanthropic activities ${ }^{41}$ which have demonstrated to some extent the socio-economic and political role played by the Sufi scholars of both male and female gender in Nigeria. Their roles

Mustapha, "Sabotage in Patronage: Islamic Education Under Colonial Rule in Nigeria," Journal of the Nigeria Association of Teachers of Arabic and Islamic Studies (NATAIS) 5, no. 1 (2001): 5-10.

36 Jean Boyd and Beverly B. Mack, The Collected Works of Nana Asma'u Daughter of Usman Dan Fodio (1793-1864) (Ibadan: Sam Bookman Publishers, 1999).

37 Abdur-Razzaq Mustapha Balogun Solagberu, "The Role of Sufi Women in the Understanding of Shari'ah in Nigeria: A Nana Asma'u Case Study," Journal of the Department of Educational Psychology and Counselling, 2007, 28-29.

38 Muhammad Dangana, "The Intellectual Contribution of Nana Asma'u to Women Education," in Proceeding of the Conference on the Impact of 'Ulama on the Centre Sudan, ed. Abubakar Mustapha and Abubakar Garba (Maiduguri: University of Maiduguri, Centre for Trans-Saharan Studies, 1991), 2010.

39 Dangana, “The Intellectual Contribution of Nana Asma'u to Women Education,"... 209.

40 Jean Boyd, "The Role of Women Scholars in the Sokoto Caliphate" (1984), 2.

41 Shehu Umar Abdullahi, On the Search for a Viable Political Culture: Reflections on the Political Thought of Shaikh 'Abdullahi Dan-Fodio (Kaduna: New Nigerian Newspapers, 1984), 9. 
in society are not restricted to what has been mentioned. Their roles in society depend on the prevailing situation at any particular period of time. For instance, whenever there is an epidemic disease in the country, the Sufis play a certain role in either how to control its spread or provide the people with a spiritual guide.

\section{E. COVID-19 in Nigeria}

COVID-19 is the code given to an infectious disease called "Corona Virus Disease". It happens to be one of the worst epidemic diseases which the World has ever witnessed in recent time. The epidemic is reported to have been traced back to $1^{\text {st }}$ December 2019 in Wuhan, Hubei, China, and on the $31^{\text {st }}$ December 2019, the World Health Organization (WHO) was informed of the discovery of the disease. It was on the basis of this historical event that it is tagged "COVID-19". Later on, on $30^{\text {th }}$ January 2020, WHO recognized it as a pandemic. ${ }^{42}$ It was from China that the disease spread to many other countries of the world including Nigeria which had its first experience of the epidemic on the $27^{\text {th }}$ February 2020, through an Italian citizen working in the Ogun State of Nigeria, he returned from Milan, Italy to the country where he came in close contact with his colleagues at work before his status was confirmed. ${ }^{43}$ As a sequel, he imported the disease into the country and since then the pandemic disease began to spread to other parts of the country at a large rate. The situation forced President Muhammad Buhari of Nigeria to declare the pandemic as "a dangerous infectious disease" and thereby signed the "COVID-19" Regulations 2020, in late March 2020. ${ }^{44}$ It was even speculated that by $30^{\text {th }}$ March 2020, Over Seven Hundred and Seventy-Seven Thousand $(777,000)$ cases of the disease had been confirmed globally.

And in Nigeria within the period of short time i.e. between $27^{\text {th }}$ February and late March 2020, a number of confirmed cases of "COVID-19" had risen to one hundred and thirty-one (131) in some parts of the country. ${ }^{45}$ All these summed together stimulated the government to make attempt to curtail the spread of the pandemic disease, coronavirus disease (COVID-19) in the country, Nigeria. Therefore, multiple efforts were made in that direction. One of such was to lockdown the country. This was eventually come into effect on Sunday $29^{\text {th }}$ March 2020 when President Muhammad Buhari shut-down Lagos and Ogun States and Federal Capital Abuja as an initial stage. State governors one after the other throughout the federation followed suit. Therefore, a nationwide lockdown was imposed, airports were ordered to be closed, flights of both international and local were canceled, and borders were shutdown. All social and religious gatherings were banned, schools including institutions of higher learning, motor parks, and markets were also closed. Certain measures such as social distance, self-isolation, wearing face-mask were imposed on the citizenry all with the aim of

42 Bukola Adenubi, “COVID-19: Which Way Nigeria,” The Nation Newspaper, April 3, 2020, 12.

43 Adenubi, "COVID-19: Which Way Nigeria,"...

44 Adenubi, "COVID-19: Which Way Nigeria,"...

45 Adenubi, "COVID-19: Which Way Nigeria,".... 
curbing the spread of COVID-19. Based on the protocol of social distance, mosques and churches were closed down. ${ }^{46}$ In order to enforce the prescribed regulations, Nigeria Centre for Disease Control (NCDC) which had been established in 2012 continues to monitor compliance with the prescribed regulations. Related to that is the formation of the task force to that effect. It is known as the National Coordinator of the Presidential Task Force (PTF) on COVID-19. All states of the Federation also established State Technical Committee on COVID-19 whereby, the state Governor himself or his Deputy or Secretary to the State Government chaired as the case might be. The State Governors continued to review their policies on COVID-19 from time to time till August September 2020 when the country was unlocked. The National policy still continues as COVID-19 of the third phrase erupted.

The effect of the pandemic and imposition of lock-down on the society and its populace was very severe, and people felt it from multiple perspectives, socially, economically, politically, educationally, and religiously. The effect of the pandemic on the people is beyond the scope of this paper. Nevertheless, the Sufis have a certain role to play at this particular or similar period.

\section{F. Role of the Sufis during COVID-19 in Nigeria}

COVID-19 is one of the worst pandemic diseases that beset the country, Nigeria. Whenever a pandemic disease occurred in the country, different methods were put in place either to serve as its remedy or to curb its spread. A number of such pandemics attracted both local and international attention. Reference can be made to such infectious diseases as Ebola, Measles, Polio, Lassa fever, Monkey Pox, and HIV-Aides. However, the gravity of all these diseases is not up to that of COVID-19. Perhaps due to its gravity, many individuals including the Sufis felt its negative impacts on their personal life as well as their religious life. For instance, the total lockdown imposed by the Government of various levels did not allow the Sufi adherents opportunities to meet and recite their daily and weekly litanies and prayers congregationally as they used to do. Closely related to that was their festivals such as Baban Dare (Mighty might's). These are:

a. Laylat 'Ashurā on the $9^{\text {th }}$ day of Muharram

b. Laylat Isrā wal Mirāj (Night Journey) staged on the $27^{\text {th }}$ day of Rajab

c. Laylat Nisf Sha'bān (Middle of Sha'ban) staged on the $14^{\text {th }}$ to $15^{\text {th }}$ day of Sha'ban

d. Laylat al-Qadr (Night of Majesty) staged on the $27^{\text {th }}$ day of Ramadan

e. Laylat 'Arafa (Night of Arafa) staged on the $9^{\text {th }}$ day of Dhul-Hijjah. ${ }^{47}$

46 “Nigeria in Lockdown," The Nation Newspaper, March 17, 2020.

47 Babatunde Muhammad Imam, "Sufi Orders and the Spread of Islam in Ilorin" (ABC/ABU Kano, 1981), 32. See also A.F. Ahmed, "The Qadiriyyah and Its Impact in Nigeria" (University of Ibadan, 1986), 269. 
In addition to all these is Laylat al-Mawhd(Birthday of the prophet). In Nigeria, the Sufis celebrate the birthday of Prophet Muhammad (SAW) (Mawtid an-Nabiy), Mawtid of Shaykh Abdul Qādir (d.1166 CE), Mawhid of Shaykh Ahmad at-Tijānī, （d. 1815 CE), Mawìd of Shaykh Ibrahīm Niyass (d. 1975 CE) ${ }^{48}$ as well as Mawtid of Shaykh Uthman Ibn Fodio (d. 1817 CE) which Shaykh Qaribullah Nasiru Kabara (Leader of the Qadiriyya in West Africa) initiated in November 2017. Closely related to the Mawhds mentioned above are the international Mawtid Celebration of Prophet Muhammad (SAW) which Tijaniyya Sufi order worldwide usually celebrate in Kaolack, the Republic of Senegal annually, many Nigerian Tijaniyya members were unable to attend because of the total lockdown. Similar to that is the international annual Mawhd of Shaykh Ibrahīm Niyass which Nigerian Tijanis usually host could not take place in its usual term. All these were the negative effect of the COVID-19 or National lockdown imposed in the country, on Sufism and the Sufis.

However, the National lockdown on the other hand can be viewed to have a positive impact on Sufism and the Sufis. For instance, many people who were not necessarily Sufi adherents engaged in the recitation of Sufi litanies as well as their involvement in the Qur'anic recitation, a number of the Sufi adherents seized the opportunity of the situation in the country to engage in extensive self-seclusion (Khalwa), examples of this positive dimension of lockdown is countless. Yet, the negative aspects of the lockdown out weighted its positive ones. People did not have a stable and peaceful state of mind as frustration and anxiety appeared on their faces.

Nevertheless, Sufis being one of the major factors responsible for the spread and understanding of Islam in West African countries, have a role to play during the pandemic in the society either as a means toward the spread of Islam or as an effort geared toward the understanding of Islam. Whatever may be the case. One has to take note that Sufism is made up of both a practical and theoretical aspect. The practical aspect consists of a series of spiritual exercises calculated to achieve the ultimate goal of life such as absorption in the Divine source as well as securing the beatific vision of Allah. ${ }^{49}$ On the other hand, Sufism as a theoretical aspect deals with the relation between soul and Allah, various degrees of spiritual perfection on the Divine path, the merging of individual will in the Divine Will, the gnosis or the esoteric knowledge, the annihilation of all human qualities and realization of the Divine Attributes, the soul's effacement (fâna) and permanency (baqā), the truth (al-Haqq) and the perfect man (Insānul-Kämil). ${ }^{50}$ The two aspects are the platforms through which the role of Sufis during the pandemic was manifested.

48 Abdur-Razzaq Mustapha Balogun Solagberu, "Mawlid Celebration amongst the Sufi Orders in Ilorin Nigeria," in The Heritage of Islam in Nigeria. Essays in Memory of Dr. Dawood Adekilekun Tijani 1942-2006), ed. Suyan Oyeweso, Mikail Adebisi Folorunsho, and Rafiu Ibrahim Adebayo (Osogbo: College of Humanity and Culture, Osun State University Osogbo, 2016), 331.

49 C.A. Qadir, Philosophy and Science in the Islamic World (London, New York: Routledge, 1988), 89.

50 Qadir, Philosophy and Science in the Islamic World. 
Pandemic Disease: It ought to be established in our minds that the Sufis like any other Muslims hold the belief that be any type of pandemic disease in a society is a form of Divine trail which can be set on any group. Qur'an draws attention to this in Qur'an 8:25 and it goes thus: "Beware of a trail that will not only affect the wrongdoers among you, and know that God is severe in punishment" ${ }^{51}$ On the basis of this, whenever a kind of disease beset a community the Sufis like other Islamic scholars approached God for remedy. This is in line with what has been stipulated in the Books of Islamic jurisprudence, whereby the performance of special prayers are recommended when there is "calamity" such as the occasion of the eclipse of the sun (Salät Kusūf Ash-Shams), prayer on the occasion of eclipse of the moon (Salāt Khusūf al-Qamar) prayer on the occasion of drought or seeking rain (Salāt al-Istisqā). ${ }^{52}$ On the occasion of COVID-19, the attitude of the Sufis does not change, because it is considered as an ailment which, according to Shaykh Abū Bakr Atīq (d. 1974) (one of the great Sufi scholars in Nigeria) is like any other type of trail which human being experience citing Qur'ān 37:145 on the sickness of Prophet Yunus thus: "But we cast him forth on the naked shore in a state of sickness. ${ }^{53}$ In another verse i.e. Qur'ān 38:41 - 44 refers to the prayer of Prophet Ayub supplicating to Allah to provide relief for him, part of the verses read thus:

"Commemorate Our Servant Ayub Behold he cried to his Lord "The Evil one has afflicted me with distress and suffering.... And gave him (back) his people and doubled their number as a grace from Ourselves and a thing for commemoration for all who have understanding... Truly We found him full of patience and constancy. How excellent in Our service. Ever did he turn (to us). ${ }^{54}$

Shaykh Atīq finally, submits that sickness is not an insult, adding that even in the Elementary Studies of Islamic theology ( Tawhì $^{\text {) }}$ sickness is considered as one of the human qualities for which a prophet of Allah cannot be discredited. ${ }^{55}$ Prophet Muhammad (SAW) on his part, had since guided the Muslim Ummah on how to curtail the spread of the pandemic in the society when he states thus:

$$
\text { اذا سمعتم بالطاعون بأرض فلا تد خلوها واذا وقع بأرض وانتم بها فلا تخرجوا منها. }
$$

Meaning:

51 Mustafa Khattab, E Clear Qur'an: A Thematic English Translation of the Message of the Final Revelation (USA: Book of Signs Foundation, 2016), 95.

52 Y.A. Quadri, Islamic Jurisprudence, Al-'Izziyyah for English Audience. Translation with Notes, trans. I.O. Oloyede (Ijebu-Ode: Shebiotimo Publications, 1990), 94-96. See also Abū Muhammad Abdullah ibn Abī Zaid, Risala A Maliki Shari'ah, trans. Bello Muhammad Daura (Zaria: Norther Nigerian Publishing Company, 1983), 50-51.

53 Abdullah Yusuf Ali, The Holy Qur'an Text, Translation and Commentary (USA: Brentwood, Maryland: Amana Corporation, 1989), 1155.

54 Ali, Abdullah Yusuf Ali, The Holy Qur'an Text, Translation and Commentary,... 1170-71.

55 Abu Bakr Atiq, Risalatu Tanbih Al-Ikhwān Bi Takdhib Sāhib Al-Khabala at-Tai'n Lijawharat AlKamal Fi Salat 'alā Sayyid Ar-Rijāl (Zaria: Gaskiya Corporation, 1972), 4-6. 
"If you hear that there is a plague in an area, do not go there. And if it occurs in the area in which you are, do not leave the place. ${ }^{556}$

Going by this prophetic tradition, one is given to understand that the issue of lockdown and the COVID-19 slogan "stay home, stay safe" is justifiable. Nevertheless, there were some Sufi scholars who expressed reservations about the COVID-19 itself. A typical reference is Shaykh Abū Bakr Yusūf, the current Khaťfa of the Tijaniyya Sufi order in the Kwara State of Nigeria. He based his submission on a pan-Islamic speech made by Shaykh Ibrahim Niyass (d. 1975) in 1964 during his proselytized trip to Ilorin - Nigeria. During the trip, Shaykh Ibrahim Niyass made reference to the 1964 Geneva meeting where the non-Muslims resolved to wage intellectual war against the Muslims, in the end, they would not be able to learn al-Qur'an in its original form, would not be able to perform their ritual prayers as stipulated and discourage them from performing holy pilgrimage to Makkah and Madinah, (hajj). Shaykh Abubakar Yusuf, therefore, interpreted all the COVID-19 guidelines such as lockdown, not allowing Muslims to perform hajj as the implementation of the 1964 Geneva Conference. ${ }^{57}$

Whatever may be the motive behind the COVID-19 and lockdown, it is a fact that Sufism as an Islamic thought aimed at achieving closeness with God in this world and hereafter as stated earlier, is made up of both practical and theoretical aspects. The Sufis abide by the two aspects irrespective of the prevailing situations, be it during the peace or calamity. The Sufi teachings are meant to guide its adherents in whatever position they find, themselves. They demonstrate their adherence to the teachings of Sufism, which are to be explained later. The art of teaching and compliance with both the practical and theoretical aspects of Sufism is the major contribution which the Sufis offer to humanity and the Sufi adherents in particular. Through that, man will achieve stability of mind, and as a result that he will overcome any form of anxiety and frustration at any particular time especially during a pandemic in a society. The same teachings and training that the Sufis continue to make available during COVID-19 in Nigeria make us consider it as the role of the Sufi during the pandemic. Bearing in mind that Allah declares in Qur'an 13:28 thus:

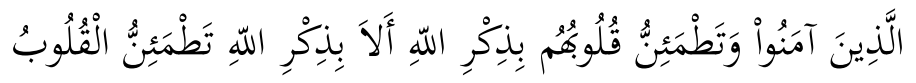

Meaning:

"Those who believe, and whose hearts find satisfaction in the remembrance of Allah, for without doubt in the remembrance of Allah do hearts find satisfaction." (Qur'an 13:28)

The practical aspects of Sufism include rituals that are observed as stipulated. The rituals are made up of litanies/prayers to be recited. The major litanies are (i) Istighfâr

56 Yasir Anjola Quadri, The Sayings of the Prophet. An Annotated Translation from Arabic to English (Ijebu-Ode: Shebiotimo Publications, 1995), 5.

57 Abubakar Sadiq Yusuf, “Auzu Billahi Mina Shaitani Rojim,” 2020. 
(Seeking Allah's forgiveness) (ii) Șalawāt alā Nabiyy (Seeking Allah's blessing for the Noble prophet S.A.W) (iii) Tahťl (Recitation of $L \bar{a}$ 'ilā illā llah) daily and on Friday there is a congregation for Dhikr al-Jumu'ah (Remembrance the name of Allah) among many others. In addition to the major litanies/prayers mentioned above, there are other occasional prayers that are recited from time to time especially during pandemics. One of such prayers reads thus:

$$
58 \text {........ صلاة تنجينا بها من الصمم والبكم والجنون والجذام والبرص وسىء الأسقام }
$$

Meaning:

“... (Oh Allah) protect us (through our supplication for the Prophet) from deafness, dumbness, madness, leukemia, leprosy, and all dreaded disease."

All these are calculated to achieve the ultimate goal of life and eventually secure the beatific vision of Allah.

The theoretical aspect of Sufism on the other hand deals with the relationship between soul and Allah, through which spiritual perfection on the Divine Path is attained. Toward that attainment, Sufi teachings such as purification of the soul, gnosis (Ma'rifa), and spiritual training (Tarbiyya) are institutionalized. The Sufis hold the belief that man ought to purify his mind, because according to them, through purification of heart and mind one will be able to undertake what is known as a spiritual journey and to become Gnostic, and as soon as one's heart is spiritually trained, all other duties that are expected of him will be possible, consequently the Sufi resilience would be attained, otherwise, one's spiritual attainment to perfection could be hindered. ${ }^{58}$ The Sufis form the theory that there are seven spiritual mystical stages of mind.${ }^{59}$ Of all the seven stages, spiritual stage number one is dangerous, while the remaining six are satisfactory. Although there are different categories, one is placed above the other. The first Sufi mystical stage is called an-Nafs al-Ammāra (The soul that is prone to evil). The name given to this Sufi mystical stage of mind is based on Qur' an 12:53. The characteristic of the mind at this stage is that he is incited to do evil. Secondly is an-Nafs al-Lawwäma (Self-reproaching mind); it is based on Qur'an 95:2. Thirdly is an-Nafs al-Mulhama (Self-inspired mind); its name is based on Qur'an 91:8. Fourthly is an-Nafs alMutma'inna (Self-satisfied mind); its name is based on Qur'an 89:27. Fifthly is an-Nafs ar-Rạ̈iya (Self-contended mind); it is based on Qur'an 89:28. Sixthly is an-Nafs alMardiyya (Self-pleased and contended mind); it is based on Qur' an 89:28. Seventhly is an-Nafs al-Kämila (A perfect mystical mind). This is the highest category of the Sufi mystical mind. There is no clear basis for it in the Qur'an. Although the Sufis accept it as a mystical stage of mind.

58 Abdul Qadir Jaylani, Sirul Asrār Fi Ma Yahtaju Ilayhil Abrār (Beirut: Dar Fikr Printing and Publishing, n.d.), 27.

59 Adam Abdullah Ilorī, Falsafat Al-Wilāyah (Agege-Lagos: Matiba'at Ath.Thaqāfal al-Islamiyyah, n.d.), 25-27. 
In the view of Shaykh Abdul Qādir Jīlāni, (the founder of Qadiriyya Sufi Order), it is mandatory for an individual on a spiritual journey to control himself to pass through spiritual mystical stages one, two and three before he can attain closeness to Allah. ${ }^{60}$ Whichever the mystical stage of mind that one must pass through before one could attain closeness to Allah, one has to embark on spiritual training known in the Sufi circle as Tarbiyya. A typical method of Tarbiyya based on the teachings of Shaykh Ibrahim Niyass (d. 1975) (An International leader of Tijaniyya) is being followed by the Tijanis globally. It can be explained thus:

Tarbiyya or spiritual training/education is a system whereby a Sufi novice (Muñd) strives to attain spiritual uplift to the extent of knowing Allah properly. And the main purpose of Tarbiyya is to control and purify one's soul and consequently become gnostic. ${ }^{61}$ The Tarbiyya is of two perspectives. These are Tarbiyya bi'l Istilāh and Tarbiyya Haqiqiyya. While the former is a form of spiritual training that involves complete retreat and seclusion from the public, minimizing the level of food consumption and engaging in constant dhikr i.e. remembrance of Allah as well as recitation of litanies/prayers. ${ }^{62}$ The latter centers on spiritual guidance based on Divine scripture, prophetic tradition, initiation of a spiritual leader as well as engagement in a constant recitation of certain prayers and litanies (adhkār). ${ }^{63}$ Based on this, it is mandated for any Sufi novice undergoing Tarbiyya to go through the companionship of Ash-Shaykh al-Wāsil (A spiritual master who has attained gnosis), who guides the novice through the spiritual journey to the desired spiritual goal. One of the litanies for Sufi Tarbiyya among the Tijaniyya Sufi order reads thus:

$$
\begin{aligned}
& \text { اللهم عليك معولى وبك ملاذى وإليك التجائى وعليك توكلى وبك ثقتى وعلى حولك وقوتك } \\
& \text { إعتمادى وبجميع مجارى أحكامك رضائى وإقرار سريان قيومتك في كل شيء وعدم إحتمال } \\
& \text { خروج شيء دقًا وجلَّ عن علمك وقهرك حتى لحظة سكونى } 65
\end{aligned}
$$

Meaning:

"O God! I put my trust in You, my refuge is with You, and I fall back on You, my confidence is in You while I rely on You. My reliance is on Your Power and

60 Jaylani, Sirul Asrār Fi Ma Yahtaju Ilayhil Abrār, 27.

61 Yasir Anjola Quadri, "The Tijaniyyah in Nigeria: A Case Study” (University of Ibadan, Nigeria, 1981), 135, 174. and See also Ya'qub Abū Bakr Al-Ghāni, Itihaf Al- Ikhwan Bi Ma'athis Ghawth AzZammaani Mawlana Ash-Shaykh Al-Hajj Ibrahim Niyass Al-Kawlakhi as-Sinighali (Kano: Maktabah wa Matba' at ash-shimali, n.d.), 90.

62 Ibrahim b. Abd. Allah Niyass, Kashf Al-Ilbās 'an Faydat Khatm Abil Abbas (Cairo: Sharikat Maktabah wal-matba' at al-mustafa al-Bābi al-Halabi, 1959), 21.

63 Niyass, Kashf Al-Ilbās 'an Faydat Khatm Abil Abbas. See also Ubaydat b. Sayyid Muhammad Saqir At-Tayshiti, Mizab Ar-Rahmat Ar-Rabbaniyyah Fil-Tarbiyyah Bi'l-Tariqah at-Tijaniyyah (Dar al-Ilm li Jāmi, 1973), 59.

65 Abū Bakr Zayd Al-Fūti, Miftāh As-Sacadat Al-Abadiyyah Fi Matālib Al-Ahmadiyyah (Tunis: Matbacah al-Manar, 1976), 132.

66 Quadri, "The Tijaniyyah in Nigeria: A Case Study," 324.

67 Ahmad Ahmadi, "Irfān and Tasawwuf," Al-Tawhid 1, no. 4 (1983): 6. 
Strength. I accept all Your Judgement with pleasure. I accept the validity of Your eternality in everything and the impossibility of anything however small or big to escape from your knowledge and might, and even the moment of my silence.'

The prayer is recited between three and seven times at the end of each of the five ritual daily prayers, during the course of the Tarbiyya and even after. It is then that the ultimate goal of life is attained.

Ahmad Ahmadi assessed a Sufi adherent at this stage of his mystical training, thus:

"At this stage, the heart is purified from all forms of turbidity, and the Divine light, by way of emanation, is reflected in one's being, and the invisible becomes visible in the immediate spiritual experience and all the veils are removed." 67

Further to that, a Sufi novice, during the process of tarbiyya passes through the concept of Mahabba (Divine love) either at the mystical station (maqāmāt) or mystical state ( $h \bar{a} I)$ as a result of which he becomes the mystical divine lover in the Sufi platform of Hāhut (Divinity) and demonstrates it in his daily life as stipulated in the Sufi platform of $N \bar{a} s \bar{t} t$ (humanity) and by implication, he has sympathy for other. And attitude which a Sufi has acquired and put into practice at any time especially during calamity like pandemics such as COVID-19 in line with the dictate of Prophet Muhammad when he states:

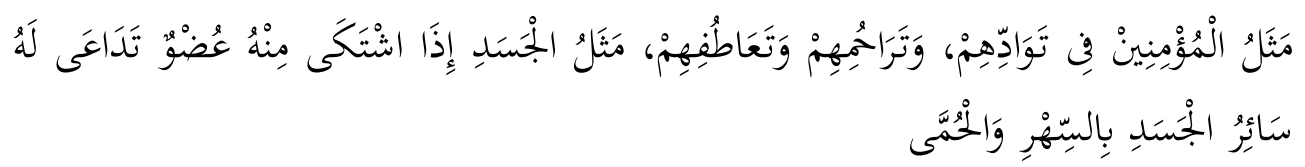

Meaning:

"The similitude of believers (in Allah) concerning their friendly relations, showing human understanding for one another, and having mutual affection for one another is like the human body. When a part of it complains, other parts of the body break down (in sympathy with it) having sleeplessness and high temperature." 68

Considering what has been discussed so far, one will realize that despite the fact that COVID-19 and lockdown brought hardship to the people in many forms, the Sufi teachings and principles have played certain roles which stabilized the adherents and provided them with what can be called the Sufi resilience by passing through another three stages identified as:

a. Takhalliya (Detachment), a situation whereby man emancipates from all sensual cravings as well as inclination, eventually the body is made free from all impurities.

b. Tahaliyya (Adornment) is a situation when man furnishes his soul with moral virtues, and

c. Tajaliyya (Illumination) is a situation that indicates immersion in Divine Essence, it also signifies abandoning egoism in order to confess in one's mind that the Creator is one and there exists nothing except Him. ${ }^{69}$ 
The knowledge and practice of Sufi are very wide; one ought to move from one stage to another. And they are not restricted to a particular space or age. As it is believed in Islam that "acquisition of knowledge is from cradle to grave" so is as it par worship, Qur' an states" And serve thy Lord until there come unto thee the Hour that is certain"70 (Qur'an 15:99).

\section{G. Conclusion}

We have discussed from the preceding paragraphs the historical background of COVID-19, how it started in China and spread to other countries of the world. In Nigeria, its discovery is traced back to $27^{\text {th }}$ February 2020 when an Italian citizen working in the country imported the disease into the country. Efforts were made to curtail its spread, and on that principle, the country was lockdown and the slogan "stay home stay safe" became a common language. The lockdown of the country had both positive and negative effects on the people, especially the Sufis, there are many Sufi rituals which are performed in the congregation such as Läzim, Wasifah, and Dhikr Jumu'ah they were no longer performed as expected. Also affected are the Sufi festivals such as Baban Dare, Mawt d celebrations among many others. Because of the fact that many Sufi activities and Islamic religion generally such as Jumu'ah prayer, pilgrimage to Makkah to perform hajj were affected. Some Sufi scholars kicked against it and considered it as an execution of the 1964 Geneva conference against Islam and the Muslims. The role played by the Sufi at that particular period is through the teaching and training of the Sufi adherents of its thoughts as well as demonstration of the practical and theoretical aspects of Sufism, through which man is more sympathetic of other's people as well as moving closer to Allah, to attain the ultimate goal of life. In the final analysis, the findings reveal that although the COVID-19 and lockdown had adverse effects on the people, the Sufi through its teachings are capable of providing resilience to the people during periods like this. In conclusion, one may recommend that further research be conducted on the Sufi Tarbiyya and its effect on the social well-being of a particular society. It is hoped that through that, many more facts will be made available and the Sufi teachings may be appreciated further. 


\section{Bibliography}

Abdullahi, Shehu Umar. On the Search for a Viable Political Culture: Reflections on the Political Thought of Shaikh 'Abdullahi Dan-Fodio. Kaduna: New Nigerian Newspapers, 1984.

Adenubi, Bukola. "COVID-19: Which Way Nigeria." The Nation Newspaper, April 3, 2020.

Ado-Kurawa, Ibrahim. Shari'ah and the Press in Nigeria, Islam versus Western Christian Civilization. Kano: Kurawa Holdings Limited, 2000.

Ahmadi, Ahmad. "Irfān and Tasawwuf." Al-Tawhid 1, no. 4 (1983).

Ahmed, A.F. “The Qadiriyyah and Its Impact in Nigeria.” University of Ibadan, 1986. . "The Spread of the Qadiriyyah in Borno and Hausa Land before the Fulani Jihad." Journal of the Nigeria Association of Teachers of Arabic and Islamic Studies 3, no. 1-4 (1983): 7.

Al-Farūqī, Ismā'il R., and Lois Lamya Al-Faruqi. The Cultural Atlas of Islam. New York: Macmillan Publishing Company \& London: Collier Macmillan Publishers, 1986.

Al-Fūti, Abū Bakr Zayd. Miftāh As-Sacadat Al-Abadiyyah Fì Matālib Al-Ahmadiyyah. Tunis: Matbacah al-Manar, 1976.

Al-Ghāni, Ya'qub Abū Bakr. Itihaf Al- Ikhwan Bi Ma'athis Ghawth Az-Zammaani Mawlana Ash-Shaykh Al-Hajj Ibrahim Niyass Al-Kawlakhi as-Sinighali. Kano: Maktabah wa Matba'at ash-shimali, n.d.

Al-Ilori, Adam Abdullahi. Al-Islām Fi Naijiriyya Wash-Shaykh 'Uthman Bin Fudiye AlFulāni. Cairo, 1971.

Al-Ilori, Ādam Abdullahi. Al İmām Al-Maghili. Cairo: Maktabah wa Matia'ah alMustafa al-Bābi al-Halabi wa awlādau, 1979.

Āthār Al-Falsafah Wat-Tasawwuf Wal-'Ilm Fi Masirah Ad-Da'Wah AlIslamiyyah. Cairo: Matba'ah al-Madni, 1982.

Ali, Abdullah Yusuf. The Holy Qur'an Text, Translation and Commentary. USA: Brentwood, Maryland: Amana Corporation, 1989.

At-Tayshiti, Ubaydat b. Sayyid Muhammad Saqir. Mizab Ar-Rahmat Ar-Rabbaniyyah Fil-Tarbiyyah Bi'l-Tariqah at-Tijaniyyah. Dar al-Ilm li Jāmi, 1973.

Atiq, Abu Bakr. Risalatu Tanbih Al-Ikhwān Bi Takdhib Sāhib Al-Khabala at-Tai'n Lijawharat Al-Kamal Fi Salat 'alā Sayyid Ar-Rijāl. Zaria: Gaskiya Corporation, 1972. 
Boyd, Jean. "The Role of Women Scholars in the Sokoto Caliphate." 1984.

Boyd, Jean, and Beverly B. Mack. The Collected Works of Nana Asma'u Daughter of Usman Dan Fodio (1793-1864). Ibadan: Sam Bookman Publishers, 1999.

Brohi, A.K. "Doctrine of Tasawwuf." In Islam in the Modern World, edited by Khurshid Ahmad. Lahore: Publishers United Ltd, 1975.

Burdon, J.A. Northern Nigeria. Historical Notes on Certain Emirates and Tribes. London: Watnow \& son Limited, 1972.

Clarke, Peter B. West Africa and Islam. London: Edward Arnold Limited, 1982.

Crowder, Rex Akpofure Michael. Nigeria: A Modern History for Schools. London: Feber and Feber, 1966.

Dangana, Muhammad. "The Intellectual Contribution of Nana Asma'u to Women Education." In Proceeding of the Conference on the Impact of 'Ulama on the Centre Sudan, edited by Abubakar Mustapha and Abubakar Garba. Maiduguri: University of Maiduguri, Centre for Trans-Saharan Studies, 1991.

Doi, Abdur-Rahman I. Islam in Nigeria. Zaria: Nigeria Gaskiya Corporation, 1984.

Ezzati, Abdul-Fazl. An Introduction to the History of the Spread of Islam. LagosNigeria: Islamic Publications Bureau, 1979.

Fajana, A., and B.J. Biggs. Nigeria in History. Ibadan: Longman Nigeria Limited, 1976.

Ilorī, Adam Abdullah. Falsafat Al-Wilāyah. Agege-Lagos: Matiba'at Ath.Thaqāfal alIslamiyyah, n.d.

Imam, Babatunde Muhammad. "Sufi Orders and the Spread of Islam in Ilorin." ABC/ABU Kano, 1981.

Jaylani, Abdul Qadir. Sirul Asrār Fi Ma Yahtaju Ilayhil Abrār. Beirut: Dar Fikr Printing and Publishing, n.d.

Johnson, Samuel. History of the Yorubas. Lagos: Nigeria C.SS limited, 2001.

Khattab, Mustafa. E Clear Qur'an: A Thematic English Translation of the Message of the Final Revelation. USA: Book of Signs Foundation, 2016.

Mustapha, Abubakar. "Sabotage in Patronage: Islamic Education Under Colonial Rule in Nigeria." Journal of the Nigeria Association of Teachers of Arabic and Islamic Studies (NATAIS) 5, no. 1 (2001): 5-10.

"Nigeria in Lockdown." The Nation Newspaper, March 17, 2020.

Niyass, Ibrahim b. Abd. Allah. Kashf Al-Ilbās 'an Faydat Khatm Abil Abbas. Cairo: Sharikat Maktabah wal-matba'at al-mustafa al-Bābi al-Halabi, 1959.

Olatunbosun, P.O. School Certificate GCE History of West African. 5th ed. Ilesha- 
Nigeria: Fatiregun Press, 1981.

Olayiwola, Abdul Fattah. Islam in Nigeria: One Cresent Many Focuses. Lagos: Nigeria Olucouger Prints, 2014.

Qadir, C.A. Philosophy and Science in the Islamic World. London, New York: Routledge, 1988.

Qadri, C.A. Philosophy and Science in Islamic World. London: Routledge, 1991.

Quadri, Y.A. Islamic Jurisprudence, Al- 'Izziyyah for English Audience. Translation with Notes. Translated by I.O. Oloyede. Ijebu-Ode: Shebiotimo Publications, 1990.

_. "The Role of the Itinerant Muqaddams in the Spread of the Tijaniyyah." Islamic Studies, Quarterly Journal XXII, no. 2 (1983): 17-29. https://www.jstor.org/stable/23076048

Quadri, Yasir Anjola. The Sayings of the Prophet. An Annotated Translation from Arabic to English. Ijebu-Ode: Shebiotimo Publications, 1995.

__. "The Tijaniyyah in Nigeria: A Case Study." University of Ibadan, Nigeria, 1981.

Saliu, Abdul Rauf. "A Critical Study of the Contribution of the School for Arabic Studies to the Development of Arabic and Islamic Studies in Nigeria." Ilorin, 1988.

Solagberu, Abdur-Razzaq Mustapha Balogun. "Mawlid Celebration amongst the Sufi Orders in Ilorin Nigeria." In The Heritage of Islam in Nigeria. Essays in Memory of Dr. Dawood Adekilekun Tijani 1942-2006), edited by Suyan Oyeweso, Mikail Adebisi Folorunsho, and Rafiu Ibrahim Adebayo. Osogbo: College of Humanity and Culture, Osun State University Osogbo, 2016.

. "Sufi versus Anti- Sufi in Ilorin Nigeria: A Struggle for Supremacy." In Ilorin: History, Culture and Lessons of Peaceful Co-Existence, edited by A.G.A.S Oladosun, Z.I. Oseni, M.A. Adedimeji, A.L Azeez, S.S Abdulbaqi, and A.G.A. Animasawun. Ilorin: Centre for Ilorin Studies, University of Ilorin, Nigeria, 2013.

. "The Role of Sufi Women in the Understanding of Shari' ah in Nigeria: A Nana Asma'u Case Study." Journal of the Department of Educational Psychology and Counselling, 2007, 28-29.

. "The Role of the Sufis in the Spread of Literacy in Nigeria." Allawh: Journal of Arabic and Islamic Studies 2, no. 4 (2009): 228-43.

Spencer, J., and Framingham. The Sufi Orders in Islam. London: Oxford University Press, 1971.

Ubah, Chinedu N. Islam in Africa History. Nigeria: Kaduna Baraka Press and Publishers Limited, 2001.

Valiudden, Mir. The Qur'anic Sufism. Delhi: Pakistan Motilal Banarsidass, 1977.

Teosofia: Indonesian Journal of Islamic Mysticism, Vol. 10, No. 2, 2021 
Yunus, Ibrahim Sālih B. At-Takfir Ahtar Bidcah Tuhadid As-Salam Wal-Wahdat Bayn Al-Muslimin Fi Naijiiriyyā. Cairo: Sharkat Maktabat Wa Matbacah Mustafa alBābī al-Halabi wa awlādau, 1982.

Yusuf, Abubakar Sadiq. “Auzu Billahi Mina Shaitani Rojim,” 2020.

Zahradeen, Muhammad Sani. "The Place of Mosque in the History of Kano.” In Studies in the History of Kano, edited by Bawuro M. Barkindo. Kano: Department of History, Bayero University, 1983.

Zaid, Abū Muhammad Abdullah ibn Abī. Risala A Maliki Shari'ah. Translated by Bello Muhammad Daura. Zaria: Northern Nigerian Publishing Company, 1983. 